\title{
JOB SECURITY FOR DISABLED WORKERS: A COMPARATIVE STUDY BETWEEN SOUTH AFRICA AND AUSTRALIA
}

\author{
Nicola Smit \\ BLC LLB LLD \\ Professor in Mercantile Law \\ University of Johannesburg \\ Robert Guthrie \\ BJuris LLB LLM MCom PhD \\ Professor of Law \\ Curtin University of Technology, Perth \\ Western Australia
}

\begin{abstract}
SUMMARY
This contribution considers issues arising from the incapacity of an employee as a result of an occupational injury or disease and the often resultant termination of the contract of employment due to an unavoidable long absence from work. A comparative approach is adopted with specific reference to the South African and Australian regulation of such cases. These cases may be divided into two main categories, namely protection against dismissal and job insecurity and then also the health and safety of workers at the workplace. Both aspects are the subject of Conventions and Recommendations of the International Labour Organisation. The similarities of the two approaches are compared (for example the protection available against unfair dismissal and unfair discrimination in labour and equity legislation) but divergences are also indicated. In particular the absence of "return to work" provisions, management of occupational injuries and the reintegration of persons injured at work in South Africa, as well as the compensation available in appropriate instances.
\end{abstract}

\section{INTRODUCTION}

Labour laws generally provide for a certain measure of job security during a reasonable absence from work due to an occupational injury (or disease). In some instances, however, the worker's absence may become unreasonably long and the operational requirements of an employer may justify the termination of employment for a valid reason after having followed a fair procedure. The question arises whether the injured worker enjoys sufficient protection in such a case. This question pertains, in essence, to the 
substantive fairness of a dismissal for reason of incapacity due to injury or disease, or, in some instances, a dismissal for operational requirements.

Dismissal is, however, not the only means by which termination of employment can take place and in some jurisdictions such as South Africa and Australia the contract of employment may be regarded as being "frustrated" as a result of long-term absence from work arising from injury or disease. In such cases the contract of employment will terminate without any action on behalf of the employer or worker where it can be established that either or both of the parties to the contract of employment are unable, by reason of circumstances or events beyond their control, to perform or complete the contract of employment. This situation is sometimes referred to as supervening impossibility of performance. In Australia the case law principles of frustration of contract have been modified by statute laws so as to provide greater employment protection for injured workers. Recent case law in both Australia and South Africa has further limited the application of this doctrine by imposing an obligation on the employer to ascertain the complete medical condition and prognosis of the employee as well as his or her prospects to recover and return to work. This paper will therefore analyse current approaches of the South African and Australian courts and parliaments to long-term absence from work and focus on these approaches to offer suggestions to improve the job security of injured workers. The paper will also consider alternative approaches or strategies that may have better regard of the important principles of rehabilitation and reintegration.

The return to work of disabled workers is an important issue which is often sadly neglected. The concept comprises at least two aspects: The right to security of employment and not to be unfairly dismissed due to an occupational injury or disease; and, the right to (return to) work upon recovery. These two aspects operate both independently and reciprocally. This paper investigates the extent to which these aspects are regulated or, alternatively, practically addressed in the South African and Australian systems.

\section{STATUTORY FRAMEWORK: SOUTH AFRICA}

\section{Background}

The most significant pieces of legislation ${ }^{1}$ in South Africa that provide for preventative safety measures in workplaces are the Occupational Health and

These Acts are currently being reviewed. There is also a common law duty on an employer to provide a healthy and safe working environment: Van Heerden v SA Pulp \& Paper Industries Ltd 1946 AD 382, Van Zyl v Workmen's Compensation Commissioner 19951 SA $708(\mathrm{~N})$; and Skinner v Minister of Public Works \& another [1998] JOL 4223 (SE). South Africa has ratified the Occupational Health and Safety Convention 155 of 1981. In addition, South Africa has adopted the SADC Charter of Fundamental Social Rights, which provides (art 12) that every worker has the right to health and safety at work as well as to a healthy and safe environment sustaining human development. 
Safety Act 85 of 1993 and the Mine Health and Safety Act 29 of $1996 .{ }^{2}$ The most important legislation that regulates the compensation of employees for work-related illness, injury and death is the Compensation for Occupational Injuries and Diseases Act 130 of 1993. The Occupational Diseases in Mines and Works Act 78 of 1973 also provides for mandatory reporting and the payment of certain benefits to workers, who work in mines and works, and who develop certain occupational lung diseases, as well as the payment of benefits for dependants of workers who die from these diseases. An employee and his or her dependants may not claim damages from the employee's employer as a result of an occupational injury or disease. ${ }^{3}$ The claim must be instituted against the Compensation Fund to which all employers (with limited exceptions) contribute. The constitutionality of this principle was upheld in Jooste $v$ Score Supermarket Trading (Pty) Ltd. ${ }^{4}$

Under the federalist Australian system, each State and Territory has a workers' compensation system, ${ }^{5}$ and in addition the Commonwealth Government also has a separate system for Commonwealth workers. ${ }^{6}$ Although the systems vary they all provide in general terms similar benefits of weekly payments, medical and rehabilitation expenses for workers who are injured or who contract disease in the course of their employment. Unlike South Africa, the right to claim damages is retained in most jurisdictions (the exceptions are South Australia and Northern Territory) although that right of action is circumscribed by strict threshold requirements based on the severity of the injury or disease. ${ }^{7}$

In Act 130 of 1993, unless the context indicates otherwise, "accident" means an accident arising out of and in the course of an employee's employment and resulting in a personal injury, illness or the death of the employee. ${ }^{8}$ An occupational injury means a personal injury sustained as a

2 The Department of Labour administers Act 85 of 1993 while the Department of Minerals and Energy administers Act 29 of 1996. According to the (draft) National Occupational Health and Safety Policy (Revised version 3 of 2003) occupational accidents and disease impose a great cost on South Africa: "In 2003 terms, this [the cost] amounts to R30 billion. Costs to employers include property damage, lost production time, lost skills as well as the cost of engaging and retaining replacements" (par 1.5).

S 35(1) of Act 130 of 1993.

1998 BCLR 1106 (CC).

5 Workers Compensation and Injury Management Act 1981 (WA), Accident Compensation Act 1985 (Vic), Workers Rehabilitation and Compensation Act 1986 (SA), Work Health Act 1986 (NT), Workplace Injury Management and Workers Compensation Act 1998 (NSW), Workers Compensation Act 1998(NSW), Workers Rehabilitation and Compensation Act 1998 (Tas), Workers Compensation and Rehabilitation Act 2003 (QId), Workers Compensation Act 1951 (ACT).

6 Safety Rehabilitation and Compensation Act 1988 (Cth).

7 Eg, Western Australia and Victoria require workers to establish a $15 \%$ whole of person impairment as a pre-requisite for commencing a common law action for negligence or delict. A full comparision of all systems can be found in the Comparison of Workers Compensation Arrangements in Australian and New Zealand June 2007 http://www.ascc.gov.au/NR/ rdonlyres/0DE24A48-028D-49A1-9631-000C899580AC/0/Aust_NZ_Comparison_07.pdf accessed 2008-08-05.

8 S 1(i). In Nicosia v Workmen's Compensation Commissioner 19543 SA 897 (T) 902 the court endorsed an earlier decision that accepted that: "To constitute an accident ... the injury must 
result of an accident. $^{9}$ An occupational disease means any disease contemplated in section 65(1)(a) or (b) of the Act. ${ }^{10}$ An employee involved in such an accident is entitled to be paid compensation. ${ }^{11}$ There should, however, be a causal connection between the accident and the loss suffered by the employee, without any actus novus interveniens. These principles apply likewise in Australia, however, the Australian jurisdictions universally allow claims for injury by accident arising out of or in the course of the employment. ${ }^{12}$ In addition all Australian jurisdictions expressly allow for gradual onset disease-type conditions of whatever kind and these are not limited to conditions found on a scheduled list (as under the South African statute). ${ }^{13}$

\section{Reintegration (and prevention)}

The Compensation for Occupational Injuries and Diseases Act (in contrast to the Australian position discussed below) mainly focuses on the payment of compensation and is somewhat silent on prevention and reintegration measures. This approach has been criticised by writers and practitioners alike. ${ }^{14}$ In a recent comprehensive investigation into the social security system of South Africa, it was the view of that Committee that:

“... unlike overwhelming precedent in this regard, no comprehensive strategy has yet been developed to incorporate prevention as part of the overall system of employment injury and disease protection. The recommendation made by the Report of the Committee of Inquiry into a National Health and Safety Council, namely that prevention policy must be developed as part of a national strategy, is supported. All compensation agencies, including the mutual associations, should participate in developing this policy."

This fairly negative view of the South African position is also held with respect to the issue of reintegration. The Committee listed examples of reintegration measures to be considered, but these did not include a prohibition on dismissal for any time neither a right to return to work:

"COIDA is not strong on reintegration measures. In contrast with the position elsewhere, there is no provision in COIDA, which specifically attempts to

be caused by some untoward or unexpected event, capable of definite ascertainment as to nature, time and place, but there need not necessarily be any agency external to the workman injured."

$9 \quad \mathrm{~S} 1(\mathrm{xxx})$.

$10 \mathrm{~S} 1$ (xxix). Therefore it includes listed diseases in schedule 3 as well as diseases falling within the open definition.

$11 \mathrm{~S} 22(1)$.

12 See eg, Kavanagh v Commonwealth (1960) 103 CLR 547; and Hatzimanolis v ANI Corp Ltd (1992) 173 CLR 473.

13 Fn 7.

14 See Benjamin and Greef Report of the Committee of Inquiry into a National Health and Safety Council in South Africa (May 1997) 164.

15 Committee of Inquiry into a Comprehensive System of Social Security for South Africa Transforming the Present Protecting the Future. Draft Consolidated Report. Report of the Committee of Inquiry into a Comprehensive System of Social Security for South Africa (March 2002) Chapter 12, par 12.5 . 
enforce reintegration measures such as compulsory rehabilitation or vocational training programmes. It is, therefore, especially in the area of reintegration measures that the system is extremely deficient. One would have to suggest that policy-makers should, as a matter of priority, consider the introduction of measures which would give effect to the principle of labour market integration. Rehabilitation, vocational training and, where appropriate, linking entitlement to benefits payment to participation in such programmes, should serve as minimal mechanisms to attain this goal."

An employer in whose service an employee was at the time of the accident or when the disease was contracted must pay the compensation due to such employee for the first three months from the date of the accident or disease. ${ }^{17}$ Thereafter the Compensation fund will refund such compensation to the employer. This provision provides some incentive for preventative action by employers but does not touch on the issue of reintegration of the employee back into the workforce.

\section{Employment security}

In South Africa, the principle of "job security" is jealously protected by both labour laws and the labour courts. Consequently employees have a right not to be unfairly dismissed. This right embraces the right to both substantive and procedural fairness in terminating a contract of employment. However, in certain circumstances there cannot be said to be a "dismissal" and in such an event employment may (lawfully) terminate. ${ }^{18}$ There are a number of common forms of termination of employment that do not fall within the definition of dismissal in the LRA. ${ }^{19}$ In the event of injured workers, these circumstances may be relevant and therefore they are briefly alluded to, but it is first necessary to describe what denotes a "dismissal" in the South African context. $^{20}$

The statutory definition of dismissal is formulated rather widely and includes, for example, the refusal to renew a fixed-term contract of employment in circumstances where there was a reasonable expectation of renewal. The first condition is that the person whose employment was terminated must have been an "employee". ${ }^{21}$ Where the employee establishes the "dismissal" it does not necessarily mean that the dismissal is unfair. The employer may then establish that the dismissal was both substantively and procedurally fair. ${ }^{22}$ Certain types of dismissals are classified as "automatically

16 Committee of Inquiry into a Comprehensive System of Social Security for South Africa Transforming the Present Protecting the Future. Draft Consolidated Report. Report of the Committee of Inquiry into a Comprehensive System of Social Security for South Africa (March 2002) Chapter 12, par 12.6

17 See s 47(3) of Act 130 of 1993

18 In these circumstances the termination is not justifiable by the CCMA or the Labour Court.

19 "Dismissal" is defined in s 186(1) of the Labour Relations Act 66 of 1995 (the Act).

20 The burden of proof rests on an employee who claims unfair dismissal to establish the existence of a dismissal (s 192(1) of the Act).

21 For the definition of an employee, refer to $s 213$ of the Act.

22 See $s$ 188(1) of the Act, which provides that if a dismissal is not automatically unfair, it is unfair if the employer fails to prove that the reason for dismissal is a fair reason related to the 
unfair" and in this instance it is not possible for the employer to establish that the dismissal was in fact fair. ${ }^{23}$

The termination of a contract of employment by the employer, with or without notice, constitutes a dismissal. In other words, a dismissal "at the initiative of the employer". ${ }^{4}$ The termination of the employment contract by the employer may be either summarily or by giving notice of intention to terminate. The notice need not be express and an employer can also indicate such intention through its actions. A similar approach has historically been taken in Australia, however, in recent times the Commonweatlh Workplace Relations Act 1996 has removed the rights of employees of small businesses to pursue unfair dismissal claims. ${ }^{25}$ Australian laws provide protection from arbitary dismissal or dismissal without proper notice ${ }^{26}$ and without justification. ${ }^{27}$ Notably this is not expressed in the form of a "right" as it is in South Africa. In a similar vein to the South African approach, Australian industrial laws require proof of termination of the employee's contract of employment at the initiative of the employer.

From the South African perspective which terminations of employment do not amount to a "dismissal"? Firstly, it must be noted that a resignation is a unilateral act by an employee that has the effect of terminating an employment contract. Unless the resignation constitutes a constructive dismissal ${ }^{28}$ it is not a dismissal in terms of the Act. ${ }^{29}$ Once an employee has resigned, the employer is under no obligation to accept any withdrawal of that resignation. ${ }^{30}$ Secondly, where an employer and an employee agree to terminate a contract of employment by mutual consent the termination is also

employee's conduct or capacity, or based on the employer's operational requirements (ie, substantive fairness), and that the dismissal was effected in accordance with a fair procedure (ie, procedural fairness). Accordingly, the Act lists three permissible grounds for dismissal, including incapacity due to ill health or injury.

$23 \mathrm{~S}$ 187(1) of the Act lists seven impermissible grounds for dismissal, including discrimination.

24 See, however, Van Niekerk, Christianson, McGregor, Smit and Van Eck Law@work (2008) par 2.1.1 (207): "The wording of the section limits its application to the termination of a contract of employment, and thus extends protection against unfair dismissal only to those persons who are employed in terms of a common law contract of employment. The effect of this limitation is that not all persons who qualify as 'employees' for the purposes of the definition in section 213 of the LRA may claim to have been dismissed under this subsection."

25 Ss 638 and 643.

$26 \mathrm{~S} 661$.

27 S 643.

28 See $\mathrm{s} 186(1)(\mathrm{e})$ of the Act

29 At common law, there is no need for a resignation to be "accepted" by an employer before it takes effect (although the Labour Appeal Court in CEPPWAWU \& Another $v$ Glass \& Aluminium 2000 CC [2002] 5 BLLR 399 (LAC) stated that: "[r]esignation brings the contract to an end if it is accepted by the employer" (406 par 33)). The common law position is, it is respectfully submitted, correct. In order to determine whether there was a resignation, the court has to evaluate what the intention of the parties was.

30 This point was recently upheld by an arbitrator in Samuels v B\&G Displays (2005) 26 ILJ 1145 (BCA). The employee had resigned, and then stated that he wished to withdraw the resignation. The arbitrator held that the employer's refusal to accept the withdrawal did not constitute a dismissal as defined by the Act, because an employee cannot withdraw a resignation once the employer accepts it. See also SACWU obo Sithole $v$ Afrox Gas Equipment Factory (Pty) Ltd [2006] 6 BALR 592 (MEIBC). 
not a dismissal. ${ }^{31}$ In the third instance, at common law, a contract of employment terminates on the death of either party and in these circumstances there is no mention of a dismissal. The fourth instance is probably the most problematic one, namely supervening impossibility of performance. In many instances relating to occupational injuries and diseases, performance of the employee's main duty (the rendering of his or her labour potential) becomes impossible. Van Niekerk et al distinguish between two possibilities: ${ }^{32}$

\begin{abstract}
"A distinction is drawn between temporary and permanent impossibility. In the former case, any obligation to perform in terms of the contract is suspended - in the latter case, the contract terminates automatically. In an employment context this principle has been applied to employees who are absent for protracted periods, usually as a result of their detention or imprisonment. Other cases have dealt with protracted absence on account of illness or some other incapacity. Although the common-law rules are shot through with various statutory entitlements to annual leave and sick leave, when these are exhausted and, in some cases at least, before that point, it is conceivable that a contract of employment might terminate by operation of law when its continued performance becomes impossible."
\end{abstract}

The Australian approach is very similar to that outlined above. Constructive dismissal if established will provide evidence of termination at the initiative ${ }^{34}$ of the employer, but otherwise at the death of a party, ${ }^{35}$ termination by mutual consent $^{36}$ and termination by a frustrating event ${ }^{33}$ (similar to the notion of impossibility) will bring a contract of employment to an end in Australia, as a matter of law and not as a consequence of the actions of the employer.

In those cases where there is a termination of employment at the initiative of the employer, in other words a "dismissal", the Act does recognise incapacity as a legitimate ground for dismissal. ${ }^{38}$ The Code of Good Practice: Dismissal ${ }^{39}$ elaborates and includes two forms of incapacity - poor work performance and ill health or injury. Where the employee's incapacity to

${ }^{31}$ Van Niekerk et al further elaborate (218): "When an employee settles a claim or waives a right to pursue it, there may have been a dismissal, but the employee agrees not to pursue a claim for relief consequent on the dismissal. A mutually agreed termination of employment occurs when there is no unilateral termination of employment by the employer. In these circumstances the contract terminates as a consequence of their agreement and there is no 'dismissal'. A termination of employment in these circumstances assumes that the employee enters into the agreement with full knowledge of its implications, and that there has been no misrepresentation by the employer that induced the employee to conclude the agreement. The court will examine all of the relevant facts and circumstances and determine whether the employee left the employer's employ of his or her own volition."

32218.

33 See also FAWU obo Meyer v Rainbow Chickens [2003] 2 BALR 140 (CCMA); Mills v Drake International SA (Pty) Ltd (2004) 25 ILJ 1519 (CCMA); and Mhlungu v Gremick Integrated Security Specialists (a division of Servest Pty Ltd) (2001) 22 ILJ 1030 (CCMA).

34 Per Mohazab v Dick Smith Electronics (No 2 )(1995) 62 IR 200 and Woolworths (SA) Pty Ltd $v$ Russian (1996) 66 IR 13.

35 Bromhead v Graham [2007] NSWCA 257.

${ }^{36}$ Quinn v Jack Chia [1992] 1 VR 567.

37 Hilton Hotels v Pasovska (2003) 122 IR 428.

$38 \mathrm{~S} 188(1)$ of the Act.

39 Schedule 8 to the Act. 
perform to the required performance standard is the result of a physical or mental condition, this would usually be covered by the rules relevant to incapacity in the form of ill health or injury. Likewise in Australia an employee's contract of employment may be lawfully terminated if his or her work performance is poor. ${ }^{40}$ In cases involving disability employers should be careful not to act in such a way that it could be viewed as unfair discrimination on that ground, as this would bring the possibility of an "automatically unfair" dismissal into play. ${ }^{41}$

Whilst there are considerable similarities between South Africa and Australia in relation to the rights of injured or disabled employees, the position in South Africa is given particularly detailed attention under the Code of Good Practice which establishes the following guidelines for dismissals for incapacity arising out of ill health and injury:

An employer must establish if the employee's ill health or injury is of a permanent or temporary nature:

(i) If the employee's ill health or injury is of a temporary nature, but the employee is likely to be absent from work for an unreasonably long time, the employer should investigate all alternatives short of dismissal. When alternatives are considered, factors such as the nature of the job, the period of absence, the seriousness of the illness or injury, and the possibility of making use of temporary employees should be taken into account;

(ii) in the case of permanent ill health or injury, the employer should consider the possibility of securing alternative employment or ways to accommodate the employee's disability;

- the employee should be afforded the opportunity to state a case in response and to be assisted by a trade union representative or fellow employee in an investigation into the employee's medical incapacity;

- when the cause of the incapacity is drug- or alcohol-related, counselling and rehabilitation may be appropriate steps for the employer to consider;

- the degree of incapacity should be considered as this is relevant to the fairness of any dismissal; and

- the Code expressly states that particular consideration should be given to employees who are injured at work or who are incapacitated by a work-related illness. The Code continues to state that: "The courts have indicated that the duty on the employer to accommodate the incapacity of the employee is more onerous in these circumstances". ${ }^{42}$

Any person who must determine the fairness of a dismissal arising from ill health or injury in a dispute must consider:

$40 \quad$ Elcom v Electrical Trades Union (1983) 5 IR 267.

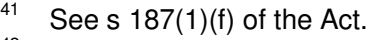

42 Code of Good Practice, item 10(4). 
(i) Whether or not the employee is capable of performing the work;

(ii) if the employee is not capable of performing the work:

the extent to which the employee is able to perform the work;

the extent to which the employee's work circumstances might be adapted to accommodate disability or, where this is not possible, the extent to which the employee's duties might be adapted; and

the availability of any suitable alternative work.

An employer should therefore discuss the employee's medical condition with the employee and/or his representative. The employer will have to ascertain the likely duration of the employee's absence from work. In the case of permanent incapacity the employer must consider alternative employment or adapting the employee's duties or work circumstances, where possible, to accommodate any disability on the part of the employee. This regulation presupposes that the employee, although permanently incapacitated, is capable of performing some work. In these circumstances the employer's obligations are similar to those that apply in the case of employees with a disability, as regulated in terms of the Employment Equity Act 55 of 1998 (the 1998 Act):

"The affirmative action measures required by the EEA include making reasonable accommodation for employees from designated groups in order to ensure that they enjoy equitable representation and that they are equitably represented in the workforce. 'Reasonable accommodation' is defined in section 1 of the EEA to mean 'any modification or adjustment to a job or to the working environment that will enable a person with a disability to have access to, participate in or advance in employment".

In National Education Health \& Allied Workers Union on behalf of Lucas and Department of Health (Western Cape), ${ }^{44}$ the arbitrator found that in the course of determining whether or not a dismissal based on incapacity was fair, regard should have been had to whether or not an employee is a person with a disability as defined in the 1998 Act. The objective of both the Labour Relations Act and the 1998 Act is to encourage employers to accommodate people with disabilities in employment if possible. The arbitrator opined that the general objective of the statutory instruments (both statutes) was to promote procedural and substantive fairness in relation to such people, and to encourage employers to keep people with disabilities in employment if these disabilities could reasonably be accommodated. It was thus found that the general concept of fairness required of the employer to consider whether

43 Van Niekerk et al 256.

44 (2004) 25 ILJ 2091 (BCA). The applicant employee was injured on duty, which resulted in her not being able to bend and lift heavy objects. As she was previously employed as a general worker in the nursing department of a hospital she was transferred to the sewing department while her case was considered. There, however, she did not cope well. She applied for a more senior administrative post but was unsuccessful. Her employment was consequently terminated on grounds of incapacity due to ill health or injury and the employer purported to have complied with items 10 and 11 of the Labour Relations Act Code of Good Practice: Dismissal. 
"reasonable accommodation" (in terms of the 1998 Act Code of Good Practice on Employment of People with Disabilities) could be made for the employee rather than to dismiss. This consideration clearly goes further than that under the Labour Relations Act Code of Dismissal. In terms of the Employment Equity Act code "reasonable accommodation" is defined in the same manner as section 1 of the 1998 Act (see item 6). An employer will therefore have to show that it made efforts to do the same. ${ }^{45}$ This interpretation is beneficial to employees and it is submitted that it should be further preferred and strengthened by arbitrators and the courts.

In Wylie v Standard Executors \& Trustees, ${ }^{46}$ an employee who suffered from a physical disability (multiple sclerosis) claimed an unfair dismissal. The commissioner distinguished between a dismissal for incapacity on the grounds of ill health (found in the LRA Code of Good Practice: Dismissal) and "disability" as defined in the 1998 Act and its code. The commissioner concluded that the requirements of these two Acts are not interchangeable and that more is required of an employer than to provide "reasonable accommodation" for an employee who falls within the definition of "people with disabilities" in terms of the 1998 Act. This decision does not detract from the decision in Lucas. The objective issue to be determined is whether or not an employee falls within the definition of a "person with a disability", as defined in

45 Refer to item 11(b)(i)-(iii). Item 6.11 of the Employment Equity Act code provides that the duty to make "reasonable accommodation" must not impose an "unjustifiable hardship" on the employer. In the case of Lucas the arbitrator stated that in deciding what is reasonable depends on the circumstances of the workplace and the employee (including the extent, the purpose, arrangements of the accommodation and the employer's resources). It may be noted that even if it is clear that there need not be an existing vacancy where an employee cannot continue to perform his or her current duties - the employer is obliged to consider adapting the duties or work circumstances of the employee. As noted above, it is also a wellestablished principle that the duty on an employer to accommodate an employee with an injury or illness is more onerous where the same was contracted as a result of his or her employment (item 10(4) of the Code of Good Practice: Dismissal). This principle was confirmed in Tshaka v Vodacom (Pty) Ltd (2005) 26 ILJ 568 (CCMA) and Standard Bank of South Africa v CCMA [2008] 4 BLLR 356 (LC). In the latter case the court formulated the legal question as follows (par 1): "What must the biggest bank in Africa do to reasonably accommodate an employee who injured her back in a motor collision whilst on duty?" Pillay J held that (par 59 et seq): "The bank failed to apply items 10 and 11 of Schedule 8 of the Code of Good Practice: Dismissal under the Labour Relations Act 66 of $1995 \ldots$ the Code of Good Practice on the Employment of People with Disabilities under the Employment Equity Act 55 of 1998 ... the Department of Labour's Code of Good Practice: Key Aspects on the Employment of People with Disabilities (2002) ... and its own incapacity management guidelines ... These instruments give effect to the Constitution of the Republic of South Africa, 1996 ... the LRA, the EEA, international and foreign law and best practice." The court confirmed that (par 60): "The origin of the test for fairness of the dismissal of an employee with disabilities is the Constitution. Various foreign and international human rights and labour instruments seek to re-enforce the protection of people with disabilities and prevent discrimination against them. The overarching policy underpinning the protection of disabled people is to give effect to human rights. In a claim based on an incapacity dismissal, the intersecting constitutional rights are rights to equality, human dignity, the right to choose a trade, occupation or profession freely and to fair labour practices."

46 (2006) 27 ILJ 2210 (CCMA). 
the 1998 Act. ${ }^{47}$ It does mean that employees with a disability will enjoy more protection than other employees injured at work and one may ask whether employees who suffer from an occupational injury or disease shouldn't be able to demand the same measure of "reasonable accommodation" from an employer. ${ }^{48}$

If an employee is permanently incapacitated to an extent that performance of the employment contract becomes impossible, in terms of strict contractual principles the question arises whether the contract terminates by operation of law or not and whether or not there is a dismissal. ${ }^{49}$ However, the law of dismissal necessitates that employers must be certain that performance in terms of the contract is indeed objectively impossible and that the employee cannot be accommodated in the current or an alternative position. Employers must also have regard to the rules of a benefit fund. Where an employee is permanently incapacitated and has successfully applied for disability benefits in terms of a benefit fund the rules may stipulate that employment is automatically terminated due to the successful application for benefits. ${ }^{50}$

As illustrated above, the Act code draws a distinction in the case of a temporary inability to work. Different procedures and requirements are set for an absence that "is unreasonably long in the circumstances" and other absences. Even in the event of an absence for an unreasonably long period the employer must still consider alternatives to dismissal. The feasibility of any available alternatives must be determined having regard to factors such as the nature of the job, the likely period of absence and the prospect of obtaining a temporary replacement for the employee. In Burger $v$ Governing Body of Newcastle Senior Primary School, ${ }^{51}$ an employee was dismissed for incapacity after she indicated that she required seven weeks' unpaid leave to undergo an operation. Since management had neither investigated the extent of the employee's incapacity nor did they give her an opportunity to state her case, her dismissal was held unfair. On the one hand this case supports the fact that a lengthy period of absence alone will not justify a dismissal on the grounds of incapacity. On the other hand, employers are often faced with "intermittent absence" and the labour courts have generally recognised an employer's right to dismiss after relatively short periods of absence if the employee has been frequently absent in the past.

The existence of any suitable alternatives to dismissal and the extent of any adaptation of duties that may be possible is a factual enquiry and should be

47 See the definition of people with disabilities in s 1 of the 1998 Act: "people who have a longterm or recurring physical or mental impairment which substantially limits their prospects of entry into, or advancement in, employment."

48 See the discussion below regarding the duty of an employer to accommodate in these circumstances.

49 See the discussion on supervening impossibility of performance above.

50 Van Niekerk et al (258) states that: "In these circumstances, the termination can be likened to a retirement on ill health and does not constitute a dismissal. If an employee is unsuccessful in qualifying for a disability benefit, the employer is not precluded from investigating of its own accord whether the employee's continued employment is viable."

51 [2005] 2 BALR 175 (CCMA). 
conducted in each case. The employer should reveal the steps it took to find alternative work that was within the employee's capability. Where such alternative work is at a reduced rate of pay it should still be considered.

Special rules exist with regard to medical incapacity that is drug- or alcoholrelated, and where the employee's incapacity is due to an occupational injury or illness. In the latter case, the Dismissal Code suggests that "particular consideration" should be given to the accommodation of these employees. This means that a higher standard will be required of employers in this situation. Nevertheless, on this basis alone there is no obligation on an employer to create a job for an employee where no such job exists, neither is there an obligation to keep any position open indefinitely.

Although the courts have been willing to scrutinise an employer's duty to accommodate, it would be helpful if a similar obligation to accommodate reasonably, as found in the EEA code, could be added to the schedule 8 code on dismissal for incapacity due to occupational injury or illness. ${ }^{53}$ In Tshaka $v$ Vodacom (Pty) $L t d^{54}$ the principle that an employer's duty to accommodate an employee is more onerous where the incapacity is work-related, was reinforced, and it was found that the fact that the dismissal was unfair because the company had not considered alternative positions outside the city where the employee was based.

52 Refer, however, again to the Lucas case regarding "reasonable accommodation" for people with disabilities.

53 See NEHAWU $v$ SA Institute for Medical Research [1997] 2 BLLR 146 (IC). For considerations of substantive fairness in these cases refer to Carr $v$ Fisons Pharmaceuticals [1994] 7 BLLR 10 (IC); Davies v Clean Deale CC (1992) 13 ILJ 1230 (IC); and NUM v Libanon Gold Mining Co Ltd (1994) 15 ILJ 585 (LAC). It is not argued that people with disabilities should not be viewed as a special vulnerable group. It is argued that protection should be similarly extended to employees suffering from an occupational injury or disease as a result of the more onerous duty on the employer to accommodate. In the Standard Bank case (n 45) the vulnerable position of workers with disabilities was underlined (see par 61): "The Constitution, several statutes including the EEA and the LRA and Codes of Practice protect employees with disabilities as a vulnerable group because they are a minority with attributes different from mainstream society. Unemployment, lower wages, poorer working conditions and barriers to promotion plague people with disabilities here and abroad. Their employment rate is less than a third of the general population. Many employers tend to exclude and marginalise employees with disabilities not merely because the disability impairs the employee's suitability for employment, but also because the employer regards the disability as an abnormality or flaw. When the attitude that disability is the problem of the disabled individual, not society, that the workplace is hazardous for disabled people and that they need to be looked after combines with paternalism, charitableness, ignorance and misinformation about disabilities, the result is that more disabled people are dismissed than accommodated. Some employers may find it more convenient to budget for a disability dismissal than to attempt to accommodate an employee. When these attitudes feature in decisions about people with disabilities, they can obscure innate prejudice, stereotyping and stigma. Able people are more inclined to bear such attitudes than disabled people" (footnotes omitted).

54 Fn 45. 


\section{Right to return to work}

There only exists a very limited "right to return to work" for an employee where such an employee is absent from work due to an occupational injury or illness - all employees have a right to sick leave in terms of the Basic Conditions of Employment Act 75 of 1997 (the "BCEA"). Employees have a right to sick leave on full remuneration, which leave is afforded in a sick leave cycle. ${ }^{55}$ Employees are entitled to the number of day's sick leave on full remuneration that the employee would work in a six-week period. For example, if an employee works a five-day week, the employee is entitled to 30 days paid sick leave in every three-year cycle. In the first six months of employment, however, an employee accumulates one day's sick leave for every 26 days worked. ${ }^{56}$ As mentioned earlier, the employer is obliged to pay an employee who suffers from an occupational injury or disease for the first three months of incapacity.

It must be stated that the widespread misconception that an employee may not be dismissed for medical incapacity unless and until the employee has exhausted the sick leave or any disability benefits to which the employee is entitled is not necessarily the case - although courts would scrutinise such a decision of an employer where the reason for the absence is an occupational injury or disease. On the other hand, an employer is also not routinely entitled to dismiss an employee once the employee has exhausted his or her leave or benefits. In each case the appropriateness of dismissal must be adjudged having regard of the factors set out above.

\section{PROTECTION OF EMPLOYEES WITH DISABILITIES UNDER THE AUSTRALIAN ANTI-DISCRIMINATION LAWS}

\section{General}

The Workplace Relations Act 1996 (Cth) governs termination of employment for workers covered by this Federal statute. As from 2006, by reason of an expansive approach adopted by the Australian High Court, it has been

55 A sick leave cycle means a period of 36 months' employment with the same employer commencing with an employee taking up employment or with the completion of an employee's prior sick leave cycle (s 22(1) of the Basic Conditions of Employment Act). In Spies v National Commissioner, SAPS [2008] JOL 21525 (LC) the applicant was absent from work for an extended period (he suffered from post traumatic stress disorder which was caused by a number of traumatic incidents which occurred during the course and scope of his employment by the South African Policy Service). After being ordered to return to work and refusing to do so, his salary was suspended. The court held that as the applicant had exhausted his sick leave and applied for permanent disability and not temporary incapacity he was on unauthorised leave there was no entitlement to pay whilst on such unauthorised leave.

56 S 22(3) of the Basic Conditions of Employment Act. The number of days sick leave utilised by an employee in the first sick leave cycle may be reduced by the number of days' sick leave taken in the first 6 months (s 22(4)). 
accepted that this statute covers nearly 85 percent of the Australian workforce who are employed by corporations. State and Territory industrial laws continue to apply, but mainly operate to protect workers employed by sole traders and partnerships. As in the case of South Africa under the Code of Good Practices, the Workplace Relations Act prohibits unfair dismissal on the grounds that it is either substantively or procedurally unfair. Importantly the Act, under the repealed section 170CK and now section 657 of the current legislation, provides that it is unlawful to dismiss an employee on the grounds of temporary absence from work because of illness or injury. Temporary absence because of illness or injury under the regulations means for a period less than 6 months. This issue was addressed in Andrews $v$ Uniting Church in Australia Frontier Services, ${ }^{57}$ where judicial registrar Mcllwaine held that the employer had unlawfully dismissed the applicant after she had been absent from work for only three weeks. This decision was made notwithstanding that at the time of the hearing (some eight months after the dismissal) the applicant was still not fit for work. The employer's precipitate action did not allow the registrar to invoke the doctrine of frustration because the case had to be considered in the light of the facts as at the date of the termination. Likewise, precipitate (and prohibited) action was taken by the employer in Emmerson v Housing Industry Association ${ }^{58}$ in dismissing a worker, then on sick leave, purportedly for wilful misconduct, because he had not returned a works vehicle which was part of his salary package. The federal court found inter alia that the employer had breached section $170 \mathrm{CK}$ in dismissing the employee due to his temporary absence because of illness, in this case chest pains. Thus, despite no medical evidence being tendered the federal court awarded $\$ 4000.00$ damages for pain, shock and humiliation resulting from the dismissal accepting that the applicant was entitled to damages for the stress reaction due to the dismissal. ${ }^{5}$

An unlawful dismissal was also established in Masters $v$ Local Boys Pty $L t d{ }^{60}$ where the employee was dismissed whilst absent from work suffering a migraine. No warning, counselling or opportunity to respond to allegations of poor performance was given to the employee, allowing the court to hold also that the dismissal was harsh, unjust and unreasonable. The employee was not, however, able to establish a claim for mental distress consequent upon termination (although this case predates Emmerson where damages of this kind have emerged). More recently, in Waghorn $v$ South Blackwater Coal Limited ${ }^{61}$ unlawful termination of employment was established where the employer attempted to invoke the terms of a certified agreement which allowed for termination of employees "whose absences form a 'pattern' and/or are above 3\% per year". Such an agreement did not prevent the worker from invoking section $170 \mathrm{CK}$, to claim termination actuated by temporary absence

Unreported AIRC 198 of 19945 May 1994.

58 [1999] FCA 5000.

59 Kocis "Breach of the Workplace Relations Act, Contract and Implied Term to Act Fairly" Sept/Oct 1999 3(1) Inhouse Counsel 4-5.

60 (1996) 40 AILR 3-419.

61 (1999) 47 AILR 4-208. 
because of illness. Where the agreement conflicted with the Act the Act prevailed. $^{62}$

As noted above in relation to the discussion of the South African Code of Good Practice there is considerable potential for workers with disabilities to be treated less favourably when they return to work. ${ }^{63}$ Australian laws also protect workers from discrimination on the grounds of temporary or permanent disability or incapacity. Australian State, Territory and Federal laws work in combination in this area. For example, federally the Disability Discrimination Act 1992 (Cth) prevents discrimination on the grounds of disability. Likewise all State and Territory jurisdictions have laws that prevent discrimination on the grounds of disability. Workers who allege discriminatory behaviour by an employer on this ground can make such a claim in a Federal or State or Territory jurisdiction. There is a difference in the remedies provided by each jurisdiction. As an example of the kinds of matters which come before the antidiscrimination tribunals, Johnstone $v$ Department of Conservation \& Natural Resources ${ }^{64}$ is instructive. In that case a tradesman who had been injured in 1986 returned to work in 1987. On his return he was given the work of an apprentice, was not given the opportunity to work on equipment and machinery with which he was familiar, and following a successful work trial was not offered a job at an alternative workshop. It was held that the worker had been treated less favourably than other workers who had not suffered a disability and damages were awarded for loss of wages, hurt, pain, humiliation and suffering.

A more difficult case under Western Australian legislation was Churchill $v$ Town of Cottesloe, ${ }^{65}$ where the applicant had been receiving compensation for hip and back injuries she sustained during the course of employment. On her return to work she was offered a promotion to clerk/cashier, which duties she gradually became unable to perform because they involved physical work which was not originally encompassed by the position. She did not receive the physical support that had been promised. She was advised to work part-time, but the employer was unable to accommodate her, insisting that she needed to be fully fit. In due course, her employment was terminated. It was held that discrimination had occurred because the medical evidence accepted by the Equal Opportunity Tribunal showed that she was fit for work, with some limitations, which the employer should have been able to accommodate. By

62 Interestingly Waghorn is also an example of an attempt to contract out of the statutory protection against unlawful dismissal on the grounds of temporary illness.

63 It is worth observing that in the USA there was some doubt as to whether a worker could bring an action for workers' compensation and for disability discrimination. It was thought that because workers had bargained away any rights to common law actions in order to secure a compensation system that no discrimination cases would be bought. It is now clear that both actions are available. See Moscowitz "Outside the 'Compensation Bargain'. Protecting the Rights of Workers on the Job to File Suits for Disability Discrimination" 1997 48(5) Labour Law Journal 272. There is no restriction on a worker in Western Australia to bring both forms of action.

64 (1993) EOC 92-533.

65 (1993) EOC 92-503. 
contrast in the earlier case of Reilly $v$ Roads Corporation, ${ }^{66}$ a claim for discrimination on the grounds of impairment was dismissed when the employer established that a worker who had been in receipt of compensation payments, could no longer perform the heavy duties required of his preaccident position. He was off work from 1986 until his dismissal in 1988. The employer also established that no light duties work was available to the worker.

It is noteworthy that Churchill was dealt with without reference to any of the Australian return to work provisions (which are discussed below), but the tribunal was prepared to require the employer to investigate thoroughly the medical evidence and attempt to modify the worker's duties to take account of any residual disability. In a Victorian decision under similar legislation, it was held that an employer was required to retrain a worker in order to assist him in complying with the inherent requirements of his job. It was accepted by the tribunal that the disability might have made him dangerous to co-workers. ${ }^{67}$ The general principle under Australian antidiscrimination legislation is that an employer must attempt to modify the work place to accommodate an employee's disability and may only decline to do so if the expense of the modification creates an unjustifiable hardship, is consistent with the South African Employment Equity Act Code of Good Practice. ${ }^{68}$

Australian job security or return to work provisions under workers' compensation legislation which require and employer to hold a job open for up to 12 months (see the discussion below) have no application if an employer offers re-employment to a worker following a compensable claim, although a dispute may arise where the worker objects to the form of work offered if it does not suit the physical capacity of that worker. If the employer makes a genuine effort to provide reasonable re-employment for the injured worker, then the worker may not claim unfair dismissal where the employment is brought to an end because of the worker's unsatisfactory work performance. An example of the latter can be seen in Cusato $v$ The Atlas Group Pty Ltd, ${ }^{69}$ where the employer and worker had agreed on a programme of return to work and rehabilitation. The worker did not return to his pre-disability work but was given alternative duties. After a period, the worker refused to return to these alternative duties and was dismissed. It was held that the employer's efforts at rehabilitation were reasonable and that the worker's expectations of the rehabilitation programme were too high and that worker's dismissal in the circumstances was not unfair. It was noted that the employer had checked with the worker's doctor to ascertain that the duties offered were suitable. However, where the return to work programme is not genuine; that is where it is so short-lived or so inappropriate in its allocation of duties as to be regarded

66 (1992) EOC 92-407.

67 Woodhouse $v$ Wood Coffill Funerals Pty Ltd (1998) EOC 92-942. In that case the employee was required to carry coffins and had difficulty doing so because of a severe leg injury. Retraining would have allowed him to adjust his gait to carry the coffins smoothly.

68 Eastman "Employers' Obligations Towards Disabled Employees" 1999 37(8) Law Society Journal 38.

69 (1998) WAIRC 1468/97 13 March 1998. 
as a sham, then the industrial tribunals may disregard that period of work and invoke return to work provisions holding that the dismissal was unfair. In other words, the employer must make a bona fide offer of re-employment or work return. ${ }^{70}$

In Garrity $v$ Commonwealth Bank of Australia, ${ }^{71}$ the Human Rights and Equal Opportunity Commission suggested that special arrangements have to be put in place for disabled employees. In Garrity, the employer was subject to the Disability Discrimination Act 1992 (Cth) which permits discrimination only where the employee is unable to perform the inherent requirements of the job and where any modifications ${ }^{72}$ would impose an unjustifiable hardship on the employer. The applicant claimed that she had, by reason of her diabetic condition and vision impairment, been denied access to the employer's policies, a career path and opportunities for transfer and promotion. She said she was not placed on a proper roster and was not provided with proper lighting and space at her workstation. The commission held that the employer had failed to accommodate the applicant's needs reasonably which would not have imposed any hardship on the employer.

It can be observed that the South African and Australian approaches to antidiscrimination as a means of protection of disabled workers are very similar. South Africa has embedded this notion constitutionally, statutorily and via a Code of Good Practice, whilst Australia relies on statutory protection. Whereas the method of implementation differs the requirements and outcomes converge.

\section{Job security for injured workers in Australia}

As noted above, save for the general employment laws and Code of Good Practice there is no specific reference to employment protection in the South African Compensation for Occupational Injuries and Diseases Act. This is a point of distinction with the Australian workers' compensation laws. In an effort to address the issues of return to work for disabled workers all Australian States and Territories have enacted provisions that attempt to provide some employment security for disabled workers as part of a rehabilitation process. ${ }^{73}$

70 Senior v Lower North Metropolitan Health Service Board of Management AIRC Print 960342 (26th July 1996).

71 (1999) EOC 92-966.

72 Discussed by the high court in Qantas Airways v Christie (1998) 152 ALR 365. See Chapman "Qantas Airways Ltd v Christie" 1998 22(3) Melbourne University LR 743-762. The court was divided on the meaning of the phrase. The majority of the court included an element of reasonableness in consideration of what was an inherent requirement of the job, importing an allowance for operational or administrative efficiency by the employer. Kirby $J$ dissented in this approach, opining that inherent requirement meant the "permanent requirements" of the position.

73 These types of provisions have a long pedigree - commencing with provisions which deemed partially incapacitated workers as totally incapacitated where the employer could not provide employment. Most notable is s 11 of the Workers Compensation Act 1926 (NSW), which provided that in the event that the employer was not able to provide suitable work for the partially disabled worker, the employer would (subject to certain requirements) be obliged to pay the worker as though he or she was totally incapacitated. There is a considerable body of 
The so-called "return to work provisions" characteristically require the employer to attempt to re-employ disabled workers provided they are able to return to some form of work within 12 months from the date of injury or disease onset. The obligations on employers usually do not apply if it is not "reasonably practicable" to provide "suitable duties" or if a worker has been dismissed on the grounds of "serious and wilful misconduct". The effectiveness and enforcement of the various provisions differ across the Australian jurisdictions. Frequently, the only recourse for dismissed disabled workers is through industrial courts and tribunals for reinstatement, because compensation jurisdictions do not generally have sufficient or effective enforcement procedures to bring about a return to work.

In relation to employment protection for disabled Victorian workers the repealed section 122 of the Accident Compensation Act 1985 (Vic) appears to have been the model for many other jurisdictions. A number of cases have evidenced attempts to invoke section 122 to support claims for unfair dismissal. $^{74}$ The relevant portions of the repealed section 122 provided as follow:

"122. Employer to re-employ worker.

(1) If within the period referred to in sub-section (3) after a worker commences to be entitled to receive weekly payments in respect of an injury arising out of or in the course of employment with an employer-

(a) the worker no longer has an incapacity for work, the employer must provide employment for the worker in a position which is the same as or equivalent to the position which he or she held before the injury;

or

(b) the worker has a current work capacity, the employer must provide suitable employment for the worker.

(2) Sub-section (1) does not apply if the employer can demonstrate to the Authority's satisfaction that it is not possible for the employer to provide employment in accordance with sub-section (1)(a) or suitable employment in accordance with sub-section (1)(b)....

(3) For the purposes of this section, the period for the purposes of sub-section (1) after a worker commences to be entitled to receive weekly payments is the period of 12 months or the sum of the periods not exceeding, in the aggregate, 12 months first occurring after the injury during which the worker has an incapacity for work ..." (own emphasis).

The question of whether repealed section 122 gives rise to any duty on the employer to provide work, or re-employ a disabled worker or gives rise to any private rights on the part of disabled workers was discussed by the Victorian supreme court in Gardiner $v$ State of Victoria. ${ }^{75}$ Gardiner had been a long-

cases that discuss the concept of "mutuality" describing the obligation of the worker to be ready, willing and able to accept suitable duties when offered by the employer. See eg, $R$. $J$ Brodie (Holdings) Pty Ltd v Pennel (1968) 117 CLR 665; and Dowell Australia Ltd $v$ Archdeacon (1975) 132 CLR 417. In the Dowell case Mason J described the burden imposed on the employer by $\mathrm{s} 11$ as "intolerable".

74 In one case an attempt to invoke s 122 was rejected because the Australian Industrial Relations Commission held that it did not have jurisdiction to apply the termination provisions of the Industrial Relations Act 1988 (Cth) for an event that occurred before they commenced operation. See Monaco v Wilson Transformer Company Pty Ltd Print 94009711 Oct 1994.

75 [1999] VSCA 100. 
term employee of the Victorian State Government. He developed a workrelated mental illness and was in due course paid compensation. He had, however, resigned his position prior to the approval of his claim. He sought to be re-employed, claiming that section 122 of the Accident Compensation Act 1985 (Vic) gave rise to a statutory duty on the employer to re-employ and that the employer had been in breach of that duty.

The Court held that, on an examination of the statute and in particular section 122, it could not be said that the provisions created any private civil rights for workers. This is because the statute was one for the public good rather than for the protection of a particular class of persons. The result, so the court held, was that no private rights accrue to a worker in these circumstances. An employer who does not comply with such a provision may be liable for a fine, but no more. Apart from Gardiner's case repealed section 122 has been invoked in a number of Victorian cases involving unfair dismissal and reinstatement. In Huang v Ford Motor Company of Australia, ${ }^{76}$ in an application by an injured worker for reinstatement, judicial registrar Murphy of the Australian Industrial Relations Commission noted the effect of the repealed section 122 was:

"This provision imposes certain obligations on an employer where an employee has an entitlement to weekly payments of compensation. Those obligations do not prevent a termination of employment being lawful under the Industrial Relations Act. The obligations remain under the Accident Compensation Act independently of the existence or non-existence of an employment contract."

However, in other cases it has been inferred that section 122 was a relevant consideration, and is a matter to be taken into account when determining if the worker had been unfairly dismissed. ${ }^{77}$ It follows that without specific referral of power to an industrial commission or tribunal to reinstate a worker based on a breach of a return to work provision, that provisions such as the repealed section 122 and others like them are more likely to give rise to prosecutions by the various WorkCover authorities around Australia. ${ }^{78}$ Notably

76 Print 9504888 Sept 1995. A similar view was taken in Dean v Moore Paragon Australia Limited Print N6866 6 Dec 1996, basically that the worker or employee had not rights under $\mathrm{s}$ 122 to seek reinstatement.

77 See eg, Tran v Calum Textiles Pty Ltd Print 97007813 March 1997. Judicial registrar Ritter, noted that $\mathrm{s} 122$ had not been breached because the employer had offered suitable duties. In Nguyen v Nissan Casting Australia Pty Ltd Print 95065715 Dec 1995 a breach of s 122 was noted as a relevant matter in determining whether the employee had been unfairly dismissed. Also under the Workers Rehabilitation and Compensation Act 1986 (SA) in Arrowcrest Group Pty Ltd v Gill (1993) 46 FCR 90, where the federal court was prepared to allow the relevant return to work provisions to be considered as a factor in an unfair dismissal case. The South Australian provisions were also considered in Bilson v George Chapman Pty Ltd [1993] SAIRC 56 and Horberry $v$ Yazaki Australia Pty Ltd (SA) Operations [1994] SAIRC 9. In Western Australian such matters have been considered as relevant considerations for unfair dismissal cases in Stockwin v Cablesands Pty Ltd (1997) WAIRC 528/96 7 Jan 1997; and Pacey v Modular Masonry (1998) WAIRC 1468/97 13 March 1998. In the Northern Territory a breach s 75A of the Work Health Act (NT) as noted in Carrigan v Darwin City Council Print 97010120 March 1997 was held to evidence lack of good faith by the employer.

78 Compliance is a quasi-criminal matter, but as Purse has shown, over the decade 1988-1998 (save for South Australia) there has not been a single prosecution under these types of 
section 122 of the Accident Compensation Act 1985 (Vic) has been repealed and reliance is now placed on section 155A of the Accident Compensation Act 1985 (Vic), to provide protection to workers. Section 122 continues to apply to workers whose injuries took place prior to March 2004. Section 155A is similar to the repealed section 122 in that it puts an onus on the employer to provide suitable duties for the injured worker for up to 12 months after the date of injury. However, section 155B provides that the employer can escape the obligation to provide suitable duties where there is unjustifiable hardship. Neither section 155A nor 155B provides any explicit enforcement mechanisms for a worker who is dismissed contrary to section 155A. Those said sections 156-163 now also provide a comprehensive right to return to work programmes. The approach evidences the growing trend in Australia towards combining 12-month employment protection clauses with employer obligations to provide rehabilitation programmes or injury management.

The Victorian provisions like those in South Australia, ${ }^{79}$ Tasmania $^{80}$ ACT, Queensland $^{81}$ and Northern Territory ${ }^{82}$ do not explicitly provide remedies for unfair dismissal for a breach of the return to work provisions. Western Australia $^{83}$ and Tasmania have similar provisions in place which provide penalties for employers who do not comply with the return to work requirements, and put in place a scheme of injury management to assist return to work. As noted above such provisions in the absence of explicit powers can be taken into account in dismissal cases. This is illustrated well in Carrigan v Darwin City Council, ${ }^{84}$ where Von Doussa J considered an unfair dismissal application under the Industrial Relations Act 1988 (Cth) based on a resignation by an employee who alleged that she was not provided with suitable duties whilst undergoing a rehabilitation programme. She alleged that she had been dismissed contrary to section 75A of the Work Health Act (NT), which provides that an employer liable to compensate an injured worker must: "(a) take all reasonable steps to provide the injured worker with suitable employment or, if unable to do so, to find suitable employment with another employer; and (b) so far as is practicable, participate in efforts to retrain the worker".

Von Doussa $\mathrm{J}$ found that the employer had failed to provide the employee with suitable duties, intending to make her work so difficult that she would resign, as in fact she did. This was a constructive dismissal and amounted to a breach of the implied term to trust and confidence. ${ }^{85}$ Consequently, it was

provisions. Purse “The Dismissal of Injured Workers and Workers' Compensation Arrangements in Australia" 2000 30(4) International Journal of Health Services 849861.

79 See ss 58A and 58B of the Workers Rehabilitation and Compensation Act 1986 (SA).

80 See s 138B of the Workers Rehabilitation and Compensation Act 1998 (Tas).

81 See ss 226-232 of the Workers Compensation and Rehabilitation Act 2003 (QId).

82 See s 75A of the Work Health Act (NT).

83 The Western Australian provision is $\mathrm{S}$ 84AA of the Workers Compensation and Injury Management Act 1981 (WA), but at the time of writing consideration was being given to amending this section to expand its scope.

84 Print 97010120 March 1997.

85 This concept is discussed in detail in A.A. Russian v Woolworths (SA) Pty Ltd [1995] SAIRC 59. 
held that the applicant's termination was unfair and the maximum (6 months' wages) compensation was awarded. ${ }^{86}$ Thus, whilst section $75 \mathrm{~A}$ of the Work Health Act (NT) did not protect the employee from dismissal directly, it did provide a backdrop against which the employer's conduct could be measured for the purposes of assessing the employer's good faith in attempting to facilitate rehabilitation.

The jurisdiction which does provide explicit powers of reinstatement of workers protected by return to work provisions is New South Wales. Section 49 of the Workplace Injury Management and Workers Compensation Act 1998 (NSW) provides that if a worker is dismissed contrary to the return to work provisions the worker may apply under part 7 chapter 2 of the Industrial Relations Act 1996 (NSW), which among other things allows the New South Wales Industrial Relations Commission to reinstate ${ }^{87}$ a worker unfairly or unlawfully dismissed to his or her former or suitable position ${ }^{88}$ and to award compensation in lieu of such an order ${ }^{89}$ At the time of writing the New South Wales model was being adopted in Western Australia and was then the subject of a bill before the Western Australian parliament, which suggests the beginnings of a trend to adopt specific referral of powers to industrial commissions and tribunals to provide remedies for disabled workers.

Interestingly, whilst reinstatement is not available explicitly under the South Australian Workers Rehabilitation and Compensation Act 1986 (SA), that Act does link failure by the employer to provide suitable duties under section $58 \mathrm{~B}$ with sections 35 and 36 . These provisions establish the employer's liability to pay compensation at the full rate where such duties are not provided, subject to the worker's upholding a mutual obligation to seek suitable duties. In addition section 67 of the Act allows WorkCover South Australia to levy increased premiums on employers who have a poor return to work record. ${ }^{90}$ Thus the South Australian legislation adopts a preventative strategy by directing the employer's attention to increased premium costs.

86 The acceptance by Von Doussa $\mathrm{J}$ of the employer's duty of trust and confidence is supported by a decision of the full bench of the industrial relations court of Australia (of which he was a member) in Burazin v Blacktown City Guardian Pty Limited (1996) 142 ALR 144151.

87 See Malkoun v Australian liquor Marketers Pty Ltd [2000] NSWIRComm 1098 (8 Sept 2000), where the worker was reinstated even after apparent settlement of the worker's claim. In Dyet v Lake Macqurie City Council [2000] NSWIRComm 140 (4 Aug 2000) the worker was refused reinstatement as the evidence disclosed that he had actively sought termination so as to facilitate the settlement of a substantial compensation claim. He was estopped from denying that he agreed to termination; there was no suggestion of constructive dismissal.

88 State Rail Authority v Bauer $J$ and Tyrell (1994) AILR 377, which was followed in Tasovac $v$ New South Wales Police Service [1999] NSWIRComm 436 (1Oct 1999).

89 See Needham v Shepparton Preserving Company Ltd (1991) AILR 395; and Johnston v Impala Kitchens Administration Pty Ltd [1998] NSWIRComm 530 (29 Sept 1998).

90 See Longyear Australia Pty Ltd $v$ Workers Rehabilitation and Compensation Corporation [1995] SASC 4951. 


\section{CONCLUSION}

The South African laws provide a solid framework for prevention of discrimination against workers injured in the course of their employment. The relevant statutes (the 1998 and 1995 Acts) dovetail and, essentially, a twofold approach can be discerned: First, there is protection from arbitrary or unfair dismissal in the industrial context (including prohibition of a discriminatory dismissal as defined in section 187 of the Act); second, there is protection from discrimination via the Constitution and by application of the Employment Equity Act and its Code of Practice. Australian laws are similar in that they also protect workers from unlawful discrimination and arbitrary dismissal. In addition to these protections Australian compensation jurisdictions have integrated specific work protection into their compensation legislation as additional protections to that offered by the industrial and antidiscrimination laws. The health and safety legislation in South Africa, as well as the compensation statute, does not positively include measures regarding job security or return to work provisions.

Common to both jurisdictions is the pro-active requirement upon employers to accommodate workers who suffer disability (whether occupational or not). It was submitted that in the case of an occupational injury or disease, the legislator should perhaps consider including guidelines (as found in the Employment Equity Act Code) regarding reasonable accommodation in the Labour Relations Act Code of Good Practice on Dismissal. It was considered that the duty to accommodate in these cases should at least be as well defined for workers suffering from occupational injury or disease as for people with disabilities even where the worker does not qualify as a "person with a disability".

The general protection under the workers' compensation regime in Australia is a 12-month quarantine on dismissal where the worker has some prospect of return to work. In effect this means a prohibition on dismissal of most injured workers for 12 months, however, the enforcement of this 12month protection differs between states. The Australian experience in this regard provides a range of useful models for South Africa. In South Africa, as described above, the first step an employer has to take is to determine whether the occupational injury or disease is permanent or temporary. This will greatly impact on any possibility of dismissal. It is also noteworthy that the concept of injury management has not taken root in South Africa as yet. This concept provides for integrated return of workers following injury or disease and is complementary to the 12-month job protection provisions. In South Africa much needs to be done regarding the reintegration and reskilling of injured workers. 